\title{
Effect of malnutrition on the pharmacokinetics of cefuroxime axetil in young rats
}

\author{
Iliana González-Hernández ${ }^{1}$, Helgi Jung-Cook ${ }^{1}$, Angela Sotelo ${ }^{1}$ \\ 1 Departamento de Farmacia, Facultad de Química, Universidad Nacional Autónoma de México (UNAM), Cd. \\ Universitaria, México, D.F., 04510, México.
}

Received July 3, 2007; Revised October 29, 2007; Accepted January 23, 2008; Published January 30, 2008.

\begin{abstract}
PURPOSE. To determine the pharmacokinetics of cefuroxime axetil in malnourished rats using a diet with a restriction in energy and nutrients (group M), a diet with a low quality protein (group K) and a good quality diet (group C) as a control. METHODS. The rats were fed with the corresponding diet for 21 days, after which a single oral dose of cefuroxime axetil (equivalent to a $2.2 \mathrm{mg}$ dose of cefuroxime) was administered and plasma samples were taken at 0 , $5,10,30,45,60,90,120,180,240,300$ and 360 minutes; samples were assayed using an HPLC assay. Biochemical parameters were measured and a microscopy study of the small intestine was carried out. After a 21 day period of recovery of the malnourished groups a second pharmacokinetic study was performed using the same sample times as those in the first study. RESULTS. In malnourished animals of group $\mathrm{K}$ the levels of plasma proteins were low and the concentrations of fat in the liver were high. The relative bioavailability of cefuroxime was $78.2 \%$ for group $\mathrm{M}$ and $64.4 \%$ for group $\mathrm{K}$. Groups $\mathrm{M}$ and $\mathrm{K}$ presented lower values of area under the curve; this means that the amount of antibiotic absorbed was lower than that of group C. In the second pharmacokinetic study although the animals received a good quality diet, it was observed that the area under the curve of group $\mathrm{K}$ was lower; the relative bioavailability was $54.3 \%$, while group M had pharmacokinetic values similar to those of the control group. CONCLUSIONS. The pharmacokinetics of cefuroxime was affected by malnutrition, suggesting that the absorption process via the transporter was modified in the malnourished groups, especially in the group fed with low quality protein.
\end{abstract}

\section{INTRODUCTION}

Severe protein energy malnutrition in children can be characterized by different syndromes known as marasmus and kwashiorkor. The factors determining whether kwashiorkor or marasmus develops remain unknown. Among other causes, diet has been proposed as a determinant factor for the development of a specific type of malnutrition. Kwashiorkor is related to the frequent use of diets poor in protein or low in good quality protein although rich in carbohydrates. Marasmus, on the other hand, is related principally to an energy deficit or to inadequate amounts of a good quality diet $(1,2)$. Other factors such as the adaptation of the organism, for example, have been proposed as determinants. Marasmus has been described as an adaptation to a deficient energy and protein intake and kwashiorkor is considered as a dysadaptation $(2,3)$. It would be helpful to establish if dietary patterns could result in one of the two types of malnutrition.

Some biochemical parameters have been used to determine the presence of malnutrition. When protein depletion becomes too severe, the adaptive mechanisms fail and the concentration of serum proteins, especially albumin, decreases. In kwashiorkor, protein deficit is higher than it is in marasmus, and for this reason, plasma proteins are in lower concentrations in kwashiorkor $(4,5)$. On the other hand, the presence of a fatty liver in children with kwashiorkor has been found.

Corresponding Author: Departamento de Farmacia, Facultad de Química, Universidad Nacional Autónoma de México (UNAM), Cd. Universitaria, México, D.F., México Tel (55) 56 2252 81, E-mail angela@servidor.unam.mx 
This biochemical change in the liver is not observed in marasmus and could be used to differentiate between the two types of severe malnutrition (6). Another characteristic of kwashiorkor is the presence of edema. It has been proposed that a decreased synthesis of plasma proteins in the liver, particularly albumin, reduces intravascular oncotic pressure. Plasma water decreases and accumulates in extravascular tissues, thus contributing to the appearance of edema.

It has been established that there is a close relationship between malnutrition and infection. Infectious diseases are major contributing and precipitating factors in protein energy malnutrition (7). The most common infections in malnourished children are those of the upper and lower respiratory tract, urinary tract infections, otitis and shigellosis, amongst others $(1,8)$. For this reason, it is necessary to use antibiotics for the treatment of malnourished children. The initial phase of the treatment, once a child is admitted to a hospital, is the administration of antibiotics and the treatment of electrolyte disturbances. The World Health Organization (WHO) recommends that all children with severe malnutrition receive parenteral ampicillin and gentamicin (9). These antibiotics are chosen because they are cheap and widely available. However, it has been demonstrated that some of the organisms related to the infections are resistant to this antimicrobial regimen (10); for this reason it may be necessary to use other types of antibiotics. Considering that in malnutrition there may be a great number of changes in pharmacokinetic or pharmacodynamic processes of xenobiotics (11-13), it is important to investigate these changes for the proper treatment of patients in order to reach appropriate concentrations of the antibiotic in the organism and avoid toxic effects of the drug.

The effects of malnutrition on drug absorption are not well characterized in the literature. For drugs that are taken via the oral route it is necessary to consider that absorption can be altered by malnutrition because of changes in the small intestine of malnourished children, which is the principal site of absorption. In the case of kwashiorkor, it has been observed that the degree of intestinal mucosa damage is an important contributor to the poor response of antibiotics in children. The changes produced in the small intestine include the combination of an increased capacity of permeation due to impaired barrier function and a decrease of absorption of some solutes owing to less absorptive surface area (14). Severe mucosal injury is more common in kwashiorkor, possibly due to the effect of protein depletion on mucosal recovery (15).

An antibiotic that is commonly used in the treatment of a variety of infections in children is cefuroxime, which is a broad-spectrum, $\beta$ lactamase-stable cephalosporin. In humans, gastrointestinal absorption of cefuroxime is negligible, whereas the acetoxyethyl ester of cefuroxime (cefuroxime axetil), an oral prodrug, shows bioavailability of 30 to $40 \%$ when taken before eating and 50 to $60 \%$ when taken after food. This prodrug is the form that has been used in children most frequently (16-18). Following absorption from the gastrointestinal tract, cefuroxime axetil is rapidly hydrolyzed by nonspecific blood esterases into cefuroxime and acetaldehyde. It has been found that prior to absorption cefuroxime axetil can be hydrolyzed in the intestinal mucosa to the non absorbable cefuroxime, this hydrolysis being proposed as one of the causes of incomplete bioavailability of the prodrug (19-22).

There are no reports on the effects of malnutrition on the pharmacokinetics of cefuroxime axetil in the published literature. This study, therefore, describes the effects of two types of malnutrition models similar to marasmus and kwashiorkor on the pharmacokinetics of cefuroxime axetil.

\section{MATERIALS AND METHODS}

Chemicals. Cefuroxime and cefuroxime axetil were provided by Kendrick Laboratories (Mexico City, Mexico). Acetonitrile and methanol were HPLC grade and were purchased from J.T. Baker (Philipsburg, NJ, USA). Bovine serum albumin and Folin reagent were purchased from Sigma-Aldrich (St. Louis, MO, USA), and chloroform, $\mathrm{NaH}_{2} \mathrm{PO}_{4}$, $\mathrm{Na}_{2} \mathrm{HPO}_{4}, \mathrm{HCl}, \mathrm{NaCl}$ were of analytical grade.

Diets. In the present study two different diets were used in order to generate malnutrition types similar to marasmus and kwashiorkor.

The diets were prepared in powder form, and the protein sources used were casein, maize 
flour, powdered milk and gelatin with appropriate additions of vitamin and mineral mixtures. The composition of the diets is shown in Table 1. Diet 1 was of good quality with sufficient amounts of energy and nutrients. A mixture of milk and casein was used to provide a good quality protein. Diet 2 consisted of a cereal as the principal source of proteins and carbohydrates. These type of diets (based on cereals) usually have a low or similar protein content as good quality diets, but the quality of the protein is frequently low. The protein mixture used for diet 2 was made with maize flour, having a low content of tryptophan, which makes this protein of low quality. In order to increase the protein content in the diet, gelatin (which has also a deficit in tryptophan) was used in the mixture. The protein content of diet 1 was $150 \mathrm{~g} / \mathrm{kg}$ with an energy content of $17.7 \mathrm{MJ} / \mathrm{kg}$ (good quality diet used for the control group) while for diet 2 the protein content was $130 \mathrm{~g} / \mathrm{kg}$ and the energy content was $17.3 \mathrm{MJ} / \mathrm{kg}$ (protein deficient diet). The total content of carbohydrates and lipids was the same for both diets $(590 \mathrm{~g} / \mathrm{kg}$ and $140 \mathrm{~g} / \mathrm{kg}$, respectively).
To adjust these contents, the composition of protein sources in diet 2 was considered, and dextrins, sucrose, dextrose as well as vegetable oil and lard were added in order to adjust carbohydrate and lipid content, respectively. The protein, fat, carbohydrate and fiber contents were determined using the AOAC analytical techniques (23).

Animals. The study protocol complied with the "Guide to the Care and Use of Experimental Animal Care" and was approved by the Animal Ethics Committee of the Universidad Nacional Autónoma de México (UNAM). Newly weaned 21 days old male Sprague-Dawley rats (Harlan, Mexico City, Mexico) weighing 35-40 g were used.

A total of 138 rats were divided into three treatment groups of 46 rats each (ten animals were used for the biochemical determinations and for the microscopy study, while the rest of the animals were used for the pharmacokinetic studies). The groups formed were: group C (control group), group $\mathrm{M}$ (malnutrition type similar to marasmus),

Table 1. Composition of the diets

\begin{tabular}{|c|c|c|}
\hline Ingredients $(\mathrm{g} / \mathrm{kg})$ & Diet 1 & Diet 2 \\
\hline Casein $(89.19 \%$ crude protein) & 84.3 & - \\
\hline Powdered milk ${ }^{1}$ & 285.2 & 49.7 \\
\hline Maize flour ${ }^{2}$ & - & 641.8 \\
\hline Gelatin $^{3}$ & - & 56.7 \\
\hline Sucrose & 159.6 & 35.8 \\
\hline Dextrose & 181.4 & 39.8 \\
\hline Dextrinized maize $\operatorname{starch}^{4}$ & 137.8 & 30.9 \\
\hline Lard & 36.4 & 57.7 \\
\hline Maize oil & 27.3 & 42.8 \\
\hline Cellulose & 45.9 & - \\
\hline Vitamin $\operatorname{mix}^{5}$ & 20.0 & 20.0 \\
\hline Roger-Harper mineral mix ${ }^{6}$ & 22.1 & 24.8 \\
\hline Total protein content $(\mathrm{g} / \mathrm{kg})$ & 150.0 & 130.0 \\
\hline Energy $\mathrm{MJ} / \mathrm{kg}$ & 17.7 & 17.3 \\
\hline \multicolumn{3}{|c|}{$\begin{array}{l}{ }^{1} \mathrm{Nido}^{\circledR},{ }^{2} \mathrm{Maseca}^{\circledR},{ }^{3} \mathrm{Knox}^{\circledR},{ }^{4} \mathrm{Maizena}^{\circledR},{ }^{5} \mathrm{ICN} \text { Pharmaceutical } 904654 \text {, Cleveland, vitamin mix }\left(\mathrm{g} \mathrm{kg}^{-1}\right. \\
\text { mixture): vitamin A acetate } 1.8 \text {, vitamin } \mathrm{D}_{2} 0.125 \text {, DL- } \alpha \text {-tocopherol acetate } 22.0 \text {, ascorbic acid } 45.0 \text {, inositol } \\
5.0 \text {, choline chloride } 75 \text {, menadione } 2.25 \text {, p-aminobenzoic acid } 5.0 \text {, niacin } 4.25 \text {, riboflavin } 1.0 \text {, pyridoxine } \\
\text { hydrochloride } 1.0 \text {, thiamine hydrochloride } 1.0 \text {, calcium pantothenate } 3.0 \text {, biotin } 0.02 \text {, folic acid } 0.09 \text {, vitamin } \\
\mathrm{B}_{12} 0.00135 ;{ }^{-1} \mathrm{ICN} \text { Pharmaceutical } 902842 \text {, Cleveland, mineral mix }\left(\mathrm{g} \mathrm{kg}^{-1} \text { mixture) Ammonium molybdate }\right. \\
0.03 \text {, calcium carbonate } 292.9 \text {, calcium phosphate.dibasic } 2 \mathrm{H}_{2} \mathrm{O} 4.3 \text {, cupric sulfate } 1.56 \text {, ferric citrate }(16- \\
17 \% \mathrm{Fe}) 6.23 \text {, magnesium sulfate. } 7 \mathrm{H}_{2} \mathrm{O} 99.8 \text {, manganese sulfate. } \mathrm{H}_{2} \mathrm{O} 1.21 \text {, potassium iodide } 0.005 \text {, } \\
\text { potassium phosphate } 343.1 \text {, sodium chloride } 250.6 \text {, sodium selenite } 0.02 \text {, zinc chloride } 0.02 \text {. }\end{array}$} \\
\hline
\end{tabular}


and group $\mathrm{K}$ (malnutrition type similar to kwashiorkor). Groups $\mathrm{C}$ and $\mathrm{K}$ were fed ad libitum with diets 1 and 2, respectively. Group $M$ was fed with diet 1 , receiving $70 \%$ of the amount of diet consumed by group $\mathrm{C}$; for this dietary regimen, in a previous study the amount of diet consumed per gram of body weight by the control group was determined and animals of group $\mathrm{M}$ received 70\% of that amount (with respect to corporal weight).

The animals were housed in a rack with individual stainless steel cages under standard animal room conditions $\left(19-22^{\circ} \mathrm{C}\right.$ room temperature, $31-60 \%$ relative humidity, and 12-h light/dark cycle). Animals of groups $\mathrm{C}$ and $\mathrm{K}$ were allowed free access to diet and the three groups received drinking-water ad libitum. The dietary regimen was maintained for 3 weeks, and the body weight of the animals was monitored periodically during this period of time, after which 10 rats of each group were sacrificed to evaluate the biochemical parameters, the rest of the animals (36 rats of each group) being used for the pharmacokinetics studies. In order to evaluate the models, the body weight of the animals was used as an index of malnutrition.

Biochemical parameters evaluation. At the end of the 3 week period, ten animals of each group were sacrificed, and the following biochemical parameters were evaluated:

Protein content. Plasma, liver and proximal segment of the small intestine protein content were measured using a modified Lowry method (24).

Total plasma protein content. Blood was taken in centrifuge tubes with sodium citrate $(0.1 \mathrm{~mL}$ per each $\mathrm{mL}$ of blood) and centrifuged at $1600 \mathrm{~g}$ for 15 minutes to separate plasma; then the protein content was measured.

Liver content of fat. The liver was removed and weighed. The organ was finely minced and homogenized using a glass homogenizer equipped with a glass pestle, adding $4 \mathrm{~mL}$ of $0.02 \mathrm{M}$ phosphate buffer per each gram of liver and adjusting the $\mathrm{pH}$ to 6 with $\mathrm{HCl} 0.1 \mathrm{~N}$. The fat content was determined using the Folch method (25).
Esterase activity determination. The intestine was rinsed with isotonic saline solution and opened longitudinally. The intestinal mucosa of the proximal segment of the intestine was scraped using a glass microscope slide and the mucosa was weighed and homogenized with isotonic saline solution 1:4 (w/v). Each mixture was then homogenized using a glass homogenizer, and stored at $-50^{\circ} \mathrm{C}$ until use. Protein content was measured, the enzymatic activity being determined by a previously reported method (20).

Microscopy study. This study was performed in the Instituto de Fisiología Celular of the UNAM. One animal of each group was sacrificed, and samples of the proximal segment of the intestine were obtained and immediately fixed in 4\% glutaraldehyde solution for subsequent investigation by transmission electron microscopy.

Pharmacokinetic studies. Two pharmacokinetic studies were performed.

Study I. After the dietary regimen of three weeks, the first pharmacokinetic study was performed. The animals were fasted overnight and received $1.3 \mathrm{~mL}$ of a $2 \mathrm{mg} / \mathrm{mL}$ solution of cefuroxime axetil (dose equivalent to $2.2 \mathrm{mg}$ cefuroxime) via oral intubation using a stainless steel ball-tipped gavage needle attached to an appropriate syringe. Rats were anaesthetized and blood samples $(1 \mathrm{~mL}$ of blood per animal) were taken via orbital sinus puncture at: 0 , $5,10,30,45,60,90,120,180,240,300$ and 360 minutes after the administration $(\mathrm{n}=3$ per sample time). The blood was centrifuged at $1600 \mathrm{~g}$ for 15 minutes and the plasma samples were stored at -50 $\pm 3{ }^{\circ} \mathrm{C}$ until use.

Study II. In order to determine if a three week recovery period had an influence on the pharmacokinetics of cefuroxime, groups $\mathrm{M}$ and $\mathrm{K}$ were fed ad libitum using the same diet as that for group $\mathrm{C}$. The feeding was maintained for 21 days, at the end of which the second pharmacokinetic study was performed using the same scheme as in period I.

Analytical procedure for the determination of plasma cefuroxime content. Cefuroxime was assayed using a high-performance liquid chromatography (HPLC) assay with a solid phase 
extraction technique for sample preparation. For validation of the method, sodium cefuroxime was used. Briefly, solid phase extraction cartridges (OASIS HLB $30 \mathrm{mg}$, Waters Corporation, MA, USA) were conditioned with $1 \mathrm{~mL}$ of methanol and equilibrated with $1 \mathrm{~mL}$ of water, then $0.5 \mathrm{~mL}$ of plasma sample was added. The cartridge was washed with $1 \mathrm{~mL}$ of $5 \%$ methanol in water $(\mathrm{v} / \mathrm{v})$, and cefuroxime was eluted with $1 \mathrm{~mL}$ of methanol. The solution was evaporated to dryness and redissolved in $0.5 \mathrm{~mL}$ of mobile phase; then $50 \mu \mathrm{L}$ was injected into the chromatographic system. Analysis was performed on a reverse phase column (Symmetry C-18, $5 \mu \mathrm{m}, 4.6$ x $150 \mathrm{~mm}$, Waters Corporation, MA, USA) using a flow rate of 1.5 $\mathrm{mL} / \mathrm{min}$ with acetonitrile and $0.05 \mathrm{M}$ sodium dihydrogen phosphate buffer ( $\mathrm{pH}$ 3), 13:87 (v/v) as a mobile phase. The analytical chromatographic system consisted of an Agilent 1100 (Agilent Technologies Inc., CA, USA) chromatograph with a quaternary pump, an automatic injector with a 100 $\mu \mathrm{L}$ loop and a diode array detector set at a wavelength of $280 \mathrm{~nm}$. The method was linear over the range of $0.25-10 \mu \mathrm{g} / \mathrm{mL}$. Intra-day coefficient of variation $(\mathrm{CV} \%)$ ranged from 0.32 to $1.62 \%$ and inter-day $\mathrm{CV}$ ranged from 9.1 to $12.0 \%$. The recovery was found to be in the range of 86 to $91 \%$. The limit of quantification was $0.25 \mu \mathrm{g} / \mathrm{mL}$.

Pharmacokinetic analysis. Pharmacokinetic parameters were determined by a non compartmental model using a WinNonLin 4.0 program (Pharsight, Mountain View, CA, USA). The pharmacokinetic parameters evaluated were: the maximum plasma concentration of the antibiotic $\left(\mathrm{C}_{\max }\right)$, the area under the plasma concentration versus time curve from 0 to the last measured concentration (AUC), the area under the plasma concentration versus time from 0 to infinity $\left(\mathrm{AUC}_{0}\right.$ to $\infty)$, the apparent volume of distribution $(\mathrm{Vd} / \mathrm{F})$, the apparent clearance $(\mathrm{CL} / \mathrm{F})$, half life $\left(\mathrm{t}_{1 / 2}\right)$ and the mean residence time of cefuroxime (MRT).

Statistical analysis. Data are expressed as means \pm SD. A one-way analysis of variance (ANOVA) was applied to compare all the parameters evaluated. The Duncan test was used in order to determine any significant difference between groups $\mathrm{M}$ and $\mathrm{K}$ when compared with the control group and also between groups $\mathrm{M}$ and $\mathrm{K}$. Differences were considered significant at $\mathrm{P}<0.05$.

\section{RESULTS}

Malnutrition models. After 3 weeks on the dietary regimen, some of the biochemical features associated with kwashiorkor and marasmus were evident in the rats fed with a restriction in energy and nutrients (group M), and with a diet of low quality protein (group K).

The results of body weight vs. time (days) are shown in Figure 1. Table 2 shows the final weight and the amount of food consumed after 21 days of feeding. A significant difference in body weight between groups was found: group $\mathrm{C}$ had the highest mean body weight, while group $\mathrm{K}$ presented the lowest. Table 2 also shows that there was a significant difference in the total amount of food consumed by the three groups. In the case of group $\mathrm{K}$, even though the animals were fed ad libitum, they consumed a significantly lower amount of food than the other two groups.

Biochemical parameters are shown in Table 3. It can be seen that the mean plasma protein content of group $\mathrm{K}$ was significantly lower $(\mathrm{P}<$ $0.05)$. In the present study no differences in the content of lipids in the liver between group $\mathrm{C}$ and $\mathrm{M}$ were found, while group $\mathrm{K}$ presented significantly higher levels.

Table 4 shows the protein content and esterase activity in the proximal segment of the small intestine. Although no significant differences in the activity of small intestine esterases among the three groups were found, both malnourished groups presented lower levels of protein in this segment of the intestine.

Figures 2 A, B and C show the microscopy observations of the proximal segment of the small intestine. In control group the absorptive cells of duodenal mucosa showed a uniform pattern, microvilli having a normal appearance. In the malnourished animals of group $\mathrm{K}$ the microvilli were shorter, some of which appeared to be fragmented. When group $\mathrm{M}$ was compared with the control group it was found that although there were apparent differences in the number of villi (even though morphometric measures were not taken) these differences were less evident than those observed in group $\mathrm{K}$. 


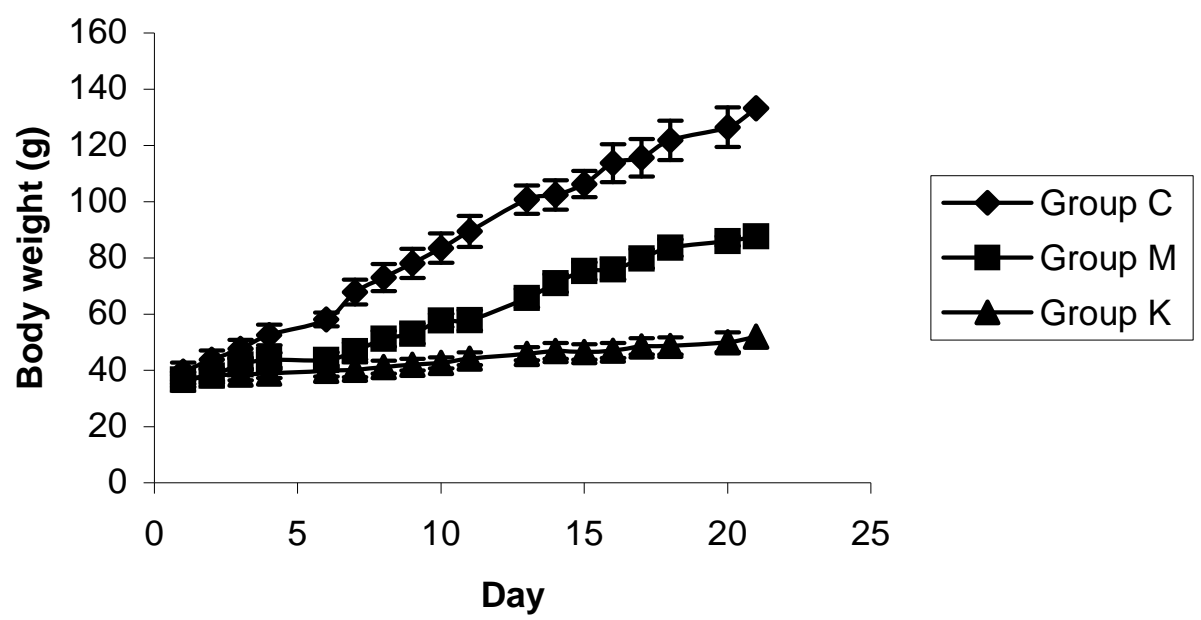

FIGURE 1. Increase in body weight as a function of time (days) during a 21-day period in groups $\mathrm{C}$ (control), $\mathrm{M}$ (restricted in energy and nutrients) and K (fed with low quality protein). Each point represents the mean body weight \pm SD. $\mathrm{n}=46$ rats.

Table 2. Body weight of the animals and amount of food consumed after 21 days of feeding ${ }^{1}$

\begin{tabular}{ccc}
\hline & Body weight & Total amount of food consumed after 21 days \\
$g$ & $g$ \\
\hline Group C & $133.3 \pm 7.0$ & $242.4 \pm 11.7$ \\
Group M & $85.9 \pm 2.9^{\mathrm{b}}$ & $118.5 \pm 2.6^{\mathrm{b}}$ \\
Group K & $51.9 \pm 3.9^{\mathrm{a}}$ & $97.3 \pm 8.3^{\mathrm{a}}$ \\
\hline
\end{tabular}

${ }^{1}$ Values are means \pm SD $n=46$

${ }^{\mathrm{a}}$ Significantly different from group $\mathrm{C}$ at $P<0.05,{ }^{\mathrm{b}}$ significantly different from groups $\mathrm{C}$ and $\mathrm{K}$ at $P<0.05$

Table 3. Biochemical parameters ${ }^{1}$

\begin{tabular}{lcc}
\hline & $\begin{array}{c}\text { Plasma proteins } \\
\mathrm{mg} / \mathrm{mL}\end{array}$ & $\begin{array}{c}\text { Liver content of fat } \\
\text { mg lipids/g protein }\end{array}$ \\
\hline Group C & $25.4 \pm 4.3$ & $64.9 \pm 10.9$ \\
Group M & $22.3 \pm 0.9$ & $62.8 \pm 7.3$ \\
Group K & $19.1 \pm 1.5^{\mathrm{a}}$ & $125.9 \pm 7.9^{\mathrm{a}}$ \\
\hline${ }^{1}$ Values are means $\pm \mathrm{SD}, \mathrm{n}=10$ & \\
${ }^{\mathrm{a}}$ Significantly different from group C at $P<0.05$ & \\
\hline
\end{tabular}

Table 4. Protein content and esterase activity in the proximal segment of the small intestine ${ }^{1}$

\begin{tabular}{ccc}
\hline & $\begin{array}{c}\text { Protein content } \\
\mathrm{mg} / \mathrm{g}\end{array}$ & $\begin{array}{c}\text { Esterase activity } \\
\mu \mathrm{g} / \mathrm{mg} \text { protein } / \mathrm{min}\end{array}$ \\
\hline Group C & $86.55 \pm 9.5$ & $0.0026 \pm 0.0005$ \\
Group M & $70.11 \pm 5.3^{\mathrm{a}}$ & $0.0024 \pm 0.0005$ \\
Group K & $68.85 \pm 4.2^{\mathrm{a}}$ & $0.0029 \pm 0.0006$ \\
\hline
\end{tabular}

${ }^{1}$ Values are means $\pm \mathrm{SD}, \mathrm{n}=10$

${ }^{\text {a }}$ Significantly different from group $\mathrm{C}$ at $P<0.05$ 
Figure 3 shows the pharmacokinetic profile of cefuroxime in plasma in the three groups from study I. In Table 5 the pharmacokinetic parameters are presented.

The AUC expressed by the dose per body weight (AUC/D) was significantly lower in malnourished groups, group $\mathrm{K}$ having the lowest value. When AUC/D values were compared, the relative bioavailability $(\mathrm{F})$ values were $78.2 \%$ for group $M$ and $64.4 \%$ for group K. Significant differences were found between malnourished groups and the control group in $\mathrm{Vz} / \mathrm{F}$. Also group $\mathrm{K}$ presented higher $\mathrm{Cl} / \mathrm{F}$ and group $\mathrm{C}$ had the lowest. No differences were found in $t_{1 / 2}$ and MRT among the three groups.

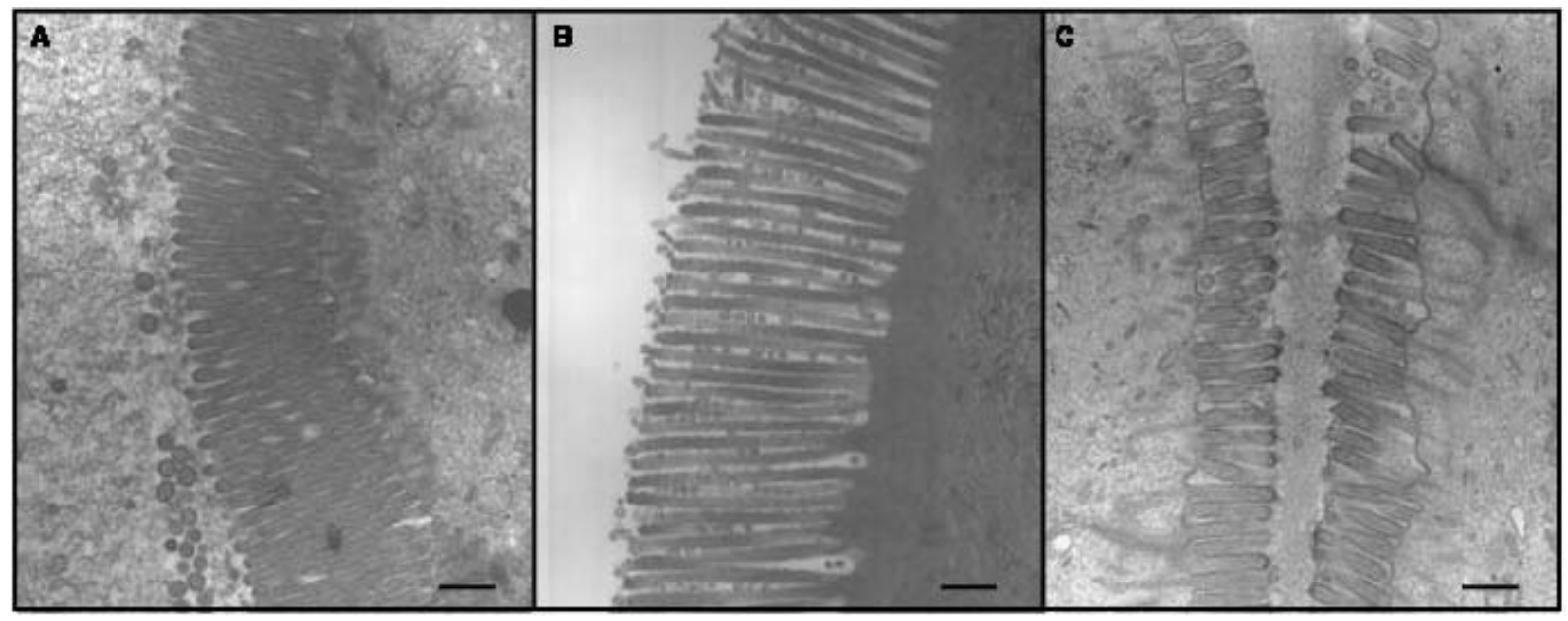

FIGURE 2. TEM images of the duodenum segment of the small intestine. Figure 2A: control group; Figure 2B: group M (restricted in energy and nutrients); Figure 2C: group K (fed with low quality protein). Barr represents $500 \mathrm{~nm}$.

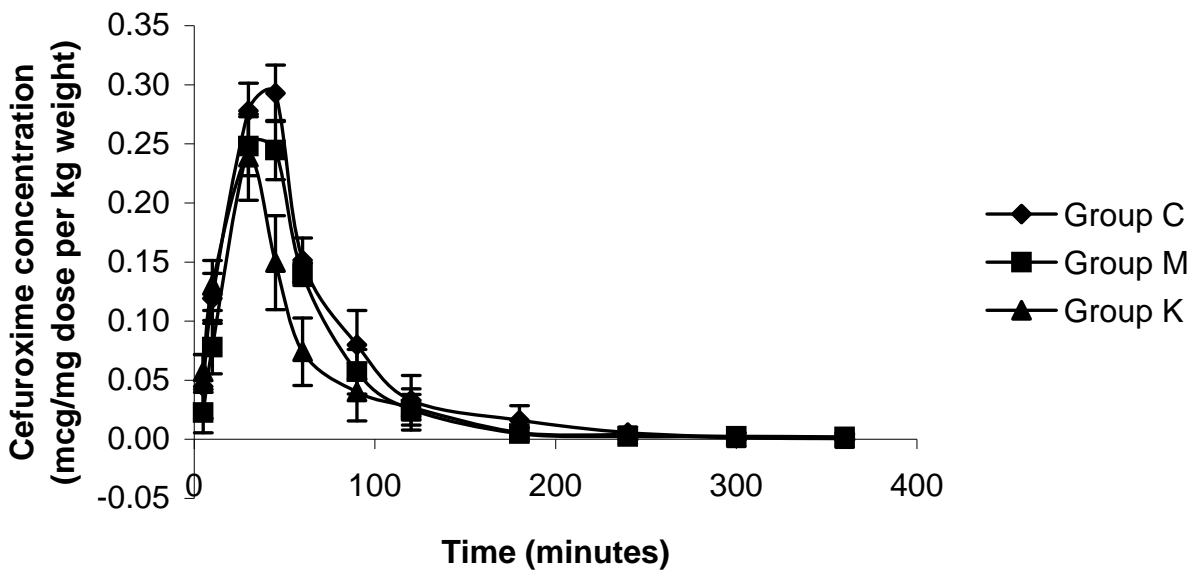

FIGURE 3. Mean plasma concentrations of cefuroxime after oral administration $(2.6 \mathrm{mg})$ of cefuroxime axetil in control and malnourished animals. Group C (control), Group M (restricted in energy and nutrients) and Group K (fed with low quality protein). 
Figure 4 shows the increase in body weight after a three week recovery period of the malnourished groups. The gain in weight during this period showed that in the first two weeks of recovery period animals of groups $\mathrm{M}$ and $\mathrm{K}$ presented a greater weight gain rate than that of the control group. However, the rate of growth of the three groups was similar during the third week, and the slope of gain weight was almost constant. At the end of the period there were still differences in corporal weight among the three groups (mean body weight: group $\mathrm{C} 214.21 \pm 12.10 \mathrm{~g}$, group $\mathrm{M}$ $193.37 \pm 10.02 \mathrm{~g}$, group K $140 . \overline{41} \pm 10.93 \mathrm{~g})$.

Table 5. Study I. Pharmacokinetic parameters of cefuroxime in control and malnourished rats. ${ }^{1}$

\begin{tabular}{lccc}
\hline & Group C & Group M & Group K \\
\hline $\mathrm{C}_{\max } / \mathrm{D}(\mu \mathrm{g} / \mathrm{mL} / \mathrm{kg})$ & $0.32 \pm 0.03$ & $0.27 \pm 0.04$ & $0.24 \pm 0.04^{\mathrm{a}}$ \\
$\mathrm{AUC} / \mathrm{D}_{0 \text { to t }}$ & $23.9 \pm 1.2$ & $18.7 \pm 1.5^{\mathrm{b}}$ & $15.4 \pm 0.7^{\mathrm{a}}$ \\
$(\mu \mathrm{g} \cdot \min \cdot \mathrm{kg} / \mathrm{mL} / \mathrm{mg})$ & & & \\
$\mathrm{AUC} / \mathrm{D}_{0}$ to $\infty$ & $24.4 \pm 1.3$ & $19.0 \pm 1.5^{\mathrm{b}}$ & $15.6 \pm 0.8^{\mathrm{a}}$ \\
$(\mu \mathrm{g} \cdot \min \cdot \mathrm{kg} / \mathrm{mL} / \mathrm{mg})$ & $2.6 \pm 0.5$ & $4.1 \pm 0.2^{\mathrm{a}}$ & $4.6 \pm 0.4^{\mathrm{a}}$ \\
$\mathrm{Vz} / \mathrm{F}(\mathrm{L} / \mathrm{kg})$ & $0.043 \pm 0.003$ & $0.054 \pm 0.004^{\mathrm{a}}$ & $0.065 \pm 0.003^{\mathrm{b}}$ \\
$\mathrm{Cl} / \mathrm{F}(\mathrm{L} / \mathrm{min} / \mathrm{kg})$ & $37.6 \pm 8.5$ & $37.0 \pm 3.5$ & $36.9 \pm 1.9$ \\
$\mathrm{t}_{1 / 2}(\min )$ & $73.2 \pm 5.6$ & $63.0 \pm 13.7$ & $64.5 \pm 5.6$ \\
$\mathrm{MRT}(\min )$ & & & \\
\hline
\end{tabular}

${ }^{1}$ Values represent means \pm SD

${ }^{a}$ Significantly different from group $\mathrm{C}$ at $P<0.05,{ }^{\text {b }}$ significantly different from groups $\mathrm{C}$ and $\mathrm{M}$ at $P<0.05$ $\mathrm{C}_{\max } / \mathrm{D}$ : maximum plasma concentration expressed by dose per corporal weight; AUC/D: area under the curve expressed by dose per corporal weight; $\mathrm{Vz} / \mathrm{F}$ : apparent volume of distribution; $\mathrm{Cl} / \mathrm{F}$ : apparent clearance; $\mathrm{t}_{1 / 2}$ : half life elimination; MRT: mean residence time

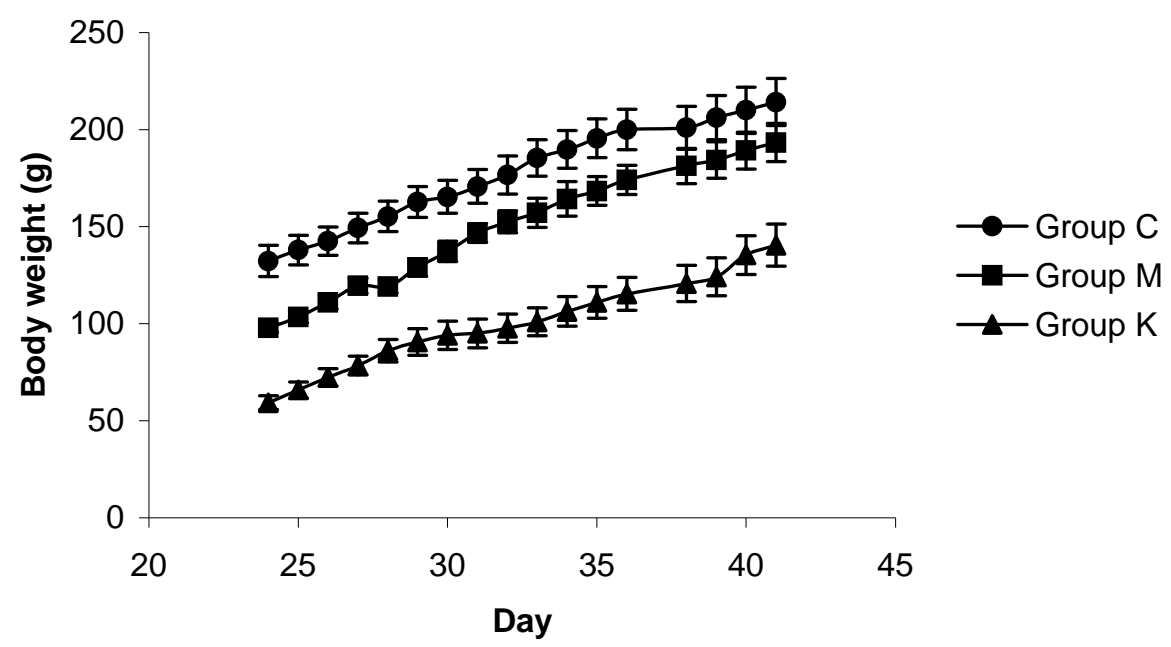

FIGURE 4. The increase in body weight as a function of time (days) during a 21-day period of recovery. Group C (control), Group M (restricted in energy and nutrients) and Group K (fed with low quality protein). Each point represents the mean body weight $\pm \mathrm{SD}, \mathrm{n}=36$ 
The pharmacokinetic profile of study II is shown in Figure 5, the pharmacokinetic parameters being presented in Table 6. Animals of group $M$ had no significant differences in any of the pharmacokinetic parameters when compared with the control group however, significant differences in $\mathrm{C}_{\max }$ and $\mathrm{AUC}$ in group $\mathrm{K}$ compared with control and $\mathrm{M}$ groups were found. For this study an $\mathrm{F}$ value of $54.3 \%$ for $\mathrm{K}$ group was found, while group $\mathrm{M}$ showed no differences in AUC/D compared with the control group, demonstrating that for this latter group the absorption of the antibiotic was similar to that of the control group, group $\mathrm{K}$ still having a lower absorption of the antibiotic. Moreover, values of $\mathrm{Vz} / \mathrm{F}$ and $\mathrm{Cl} / \mathrm{F}$ group $\mathrm{K}$ were higher than the other groups, while the value of MRT in group $\mathrm{K}$ was not significantly different from those of groups $\mathrm{C}$ and $\mathrm{M}$.

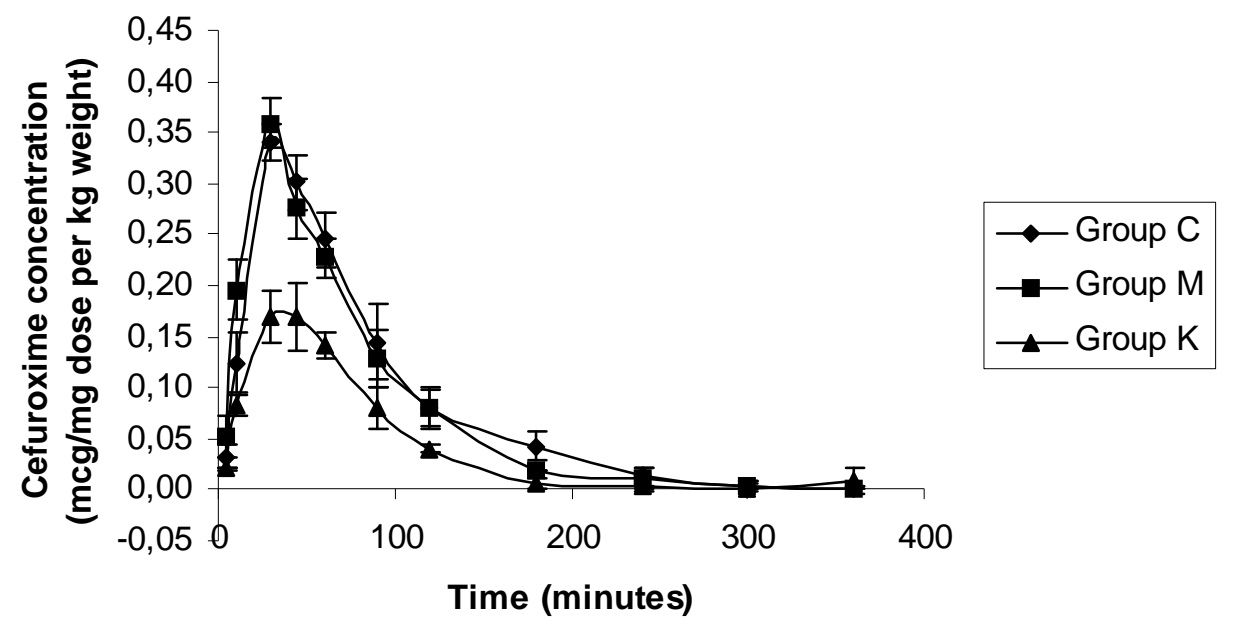

FIGURE 5. Mean plasma concentrations of cefuroxime after oral administration (2.6 $\mathrm{mg})$ of cefuroxime axetil in control and animals of groups $\mathrm{M}$ and $\mathrm{K}$ after a 21 day period of recovery. Group $\mathrm{C}$ (control), group $\mathrm{M}$ (restricted in energy and nutrients) and group $\mathrm{K}$ (fed with low quality protein).

Table 6. Study 2. Pharmacokinetic parameters of cefuroxime in control and malnourished rats after 3 weeks of recovery. ${ }^{1}$

\begin{tabular}{lccc}
\hline & Group C & Group M & Group K \\
\hline $\mathrm{C}_{\text {max }} / \mathrm{D}(\mu \mathrm{g} / \mathrm{mL} / \mathrm{kg})$ & $0.35 \pm 0.01$ & $0.38 \pm 0.06$ & $0.20 \pm 0.02^{\mathrm{a}}$ \\
$\mathrm{AUC} / \mathrm{D}_{0 \text { to }}$ & $26.9 \pm 2.1$ & $30.4 \pm 1.5$ & $14.6 \pm 1.0^{\mathrm{a}}$ \\
$(\mu \mathrm{g} \cdot \mathrm{min} \cdot \mathrm{kg} / \mathrm{mL} / \mathrm{mg})$ & & \\
$\mathrm{AUC} / \mathrm{D}_{0}$ to $\infty$ & $27.2 \pm 2.1$ & $1.9 \pm 0.4$ & $14.8 \pm 1.2^{\mathrm{a}}$ \\
$(\mu \mathrm{g} \cdot \mathrm{min} \cdot \mathrm{kg} / \mathrm{mL} / \mathrm{mg})$ & $1.9 \pm 0.3$ & $0.033 \pm 0.005$ & $3.1 \pm 0.3^{\mathrm{a}}$ \\
$\mathrm{Vz} / \mathrm{F}(\mathrm{L} / \mathrm{kg})$ & $0.036 \pm 0.004$ & $37.5 \pm 5.7$ & $0.069 \pm 0.005^{\mathrm{a}}$ \\
$\mathrm{Cl} / \mathrm{F}(\mathrm{L} / \mathrm{min} / \mathrm{kg})$ & $32.8 \pm 3.8$ & $79.06 \pm 5.3$ & $31.6 \pm 4.1$ \\
$\mathrm{t}_{1 / 2}(\mathrm{~min})$ & & $83.9 \pm 22.9$ \\
$\mathrm{MRT}(\mathrm{min})$ & $84.11 \pm 3.1$ & \\
${ }^{1} \mathrm{Values}$ are means $\pm \mathrm{SD}$ & & \\
${ }^{\mathrm{a}}$ Significantly different from groups $\mathrm{C}$ and M at $P<0.05$ & \\
$\mathrm{C}_{\max } / \mathrm{D}:$ maximum plasma concentration expressed by dose per body weight; AUC/D: area under the curve \\
expressed by dose per body weight; Vz/F: apparent volume of distribution; Cl/F: apparent clearance; $\mathrm{t}_{1 / 2}:$ half \\
life elimination; MRT: mean residence time
\end{tabular}




\section{DISCUSSION}

So far most of the pharmacokinetic studies carried out on malnourished animals have been performed using insufficient amounts of good quality foods; this means that although the food has sufficient quantities of all nutrients, including a good quality protein (with all essential amino acids in sufficient quantities), the amount of food consumed by the animal, it is not enough to accomplish the nutrimental and energy requirements of the animal. Considering that the effects of a low quality protein have not been studied and could be different from those produced by the restriction in the amount of food consumed by the animal, the main aim of this paper was to determine if different types of malnutrition had an influence on the pharmacokinetics of cefuroxime axetil.

Animal models for malnutrition are based on the consumption of low quantities of a good quality diet (to simulate marasmus) or on diets with low protein content (to simulate kwashiorkor), usually casein or albumin. Edozien (26) has reported that young rats fed on a diet containing $0.5 \%$ albumin develop the clinical features of kwashiorkor, including edema after periods from 2 to 4 months. However, the extremely low level of protein and the time to develop malnutrition can cause stress in the experimental animals. In the present work it has been possible to obtain some biochemical features found in kwashiorkor in a shorter period of time using a food with a low quality protein.

The total amount of food consumed by group $\mathrm{K}$ during the first phase of the study was significantly lower when compared with that of the control group. This behavior has been observed by other authors it probably being a consequence of a deficit in essential amino acids in the diet (27-31). Peng et al. (32) suggested that young rats were able to select a protein diet appropriate to their bodily needs. The protein consumed by group $\mathrm{K}$ was of low quality (deficient in tryptophan) and the alterations produced by the imbalanced amino acid pattern could be the reason for the limited amounts of food consumed by this group. The significantly lower body weight of this group was a result of a poor quality protein as well as the lower quantity of food consumed by the rats.

Animals of group $\mathrm{K}$ presented the lowest plasma protein content as observed in kwashiorkor. These proteins tend to be lower when protein deficiency is the principal cause of the malnutrition state and this could be the reason for the differences found between groups $\mathrm{K}$ and $\mathrm{M}$.

The content of fat in the liver in $\mathrm{M}$ group was not different from that found in the control group. Group K showed a higher content of fat liver than that of the control group. These last results are similar to those found in autopsied children with kwashiorkor, who presented higher levels of fat in the liver (33). Some authors have proposed that a severe deficiency in protein such as that observed in kwashiorkor, can cause a decrease in liver proteins that transport lipids in the organism, causing its accumulation in the organ. It is also possible that an increased hepatic fatty acid synthesis from the excess carbohydrate, an impaired fatty acid oxidation by hepatocytes or an impaired wholebody fatty acid oxidation can cause accumulation of lipids in the liver (34-36).

The microscopy study showed that the small intestine was modified by severe malnutrition mainly in group $\mathrm{K}$, which could alter the capacity of absorption by this tissue. In humans it has been observed that in kwashiorkor the villi are shortened and their number decreases owing to fusion so that the ridge or leaf-shaped villi are common; villous atrophy has also been observed $(14,37,38)$. Severe mucosal injury is more common in kwashiorkor than it is in marasmus, possibly due to the effect of protein depletion on mucosal recovery (15). This behavior was similar in group $\mathrm{K}$, which had a deficit of good quality protein and presented more damage in the small intestine than group $M$. Zambonino et. al (39), found that villus height can be used as an indicator of the nutritional state in rats, and taking this into account, group $\mathrm{K}$ presented a more severe malnourished state than did group $\mathrm{M}$.

The results obtained demonstrated that the malnutrition models of this study can be used to evaluate the changes and effects produced by these two types of malnutrition.

The results obtained in study I showed that for malnourished animals of groups $\mathrm{K}$ and $\mathrm{M}$ values of AUC/D were lower than those of the control group, which indicates that the absorbed fraction of the antibiotic was lower in the former groups. It has been reported that cefuroxime axetil can be transported by a carrier-mediated $\mathrm{pH}$-dependent peptide transporter (PepT1), but it can also be absorbed by passive diffusion (22). It is possible that the decrease in the microvilli of the small 
intestine in malnourished animals from group $\mathrm{K}$ decreased the surface available for absorption, which, as a consequence, reduced the absorption capacity of the drug. Group $M$ also showed differences in AUC/D with respect to the control group, and although this group did not show differences in the height of microvilli, a reduction in the number was apparent, a situation that could also reduce the surface area for absorption. Bae et al. (40) found a similar behavior after the oral administration of an oxazolidinone, DA-7867 to malnourished rats fed with a $5 \%$ protein diet. The AUC was significantly smaller compared with that of the control group, suggesting a decrease in gastrointestinal absorption in malnourished animals.

Esterase activity in the intestinal mucosa was measured in the proximal part of the intestine because it has been demonstrated that this fraction has a greater absorption capacity for the prodrug (21). It has been proposed that one of the reasons for the variability in cefuroxime axetil bioavailability is the existence of interindividual variability in the enzymatic activity of the intestinal esterases, since these enzymes may hydrolyze the prodrug producing the non absorbable form of the drug (cefuroxime) (19). Esterase activity in the intestinal mucosa was measured in order to determine if it could be altered by malnutrition. The protein content in the proximal segment of the small intestine was lower in both malnourished groups when compared with the control group, but no significant differences in the activity of small intestine esterases among the three groups were found; this was probably due to the homeostasis that the organism maintains in some enzymes which are required for the digestion processes. Some authors have reported that the intestinal mucosa can obtain the energy even when malnutrition is present, the energy could be obtained from the lumen itself and also the intestine is one of the first tissues exposed to the dietary nutrients; these sources could provide energy substrates to support the activity of the small intestine, so the enzymatic activity can be maintained $(41,42)$. The results obtained in esterase activity of the small intestine suggests that in malnourished groups not all changes in the bioavailability of cefuroxime axetil can be attributed to differences in esterase activity in the small intestine.

With respect to the values of $t_{1 / 2}$ found, there were no differences between groups, suggesting that the elimination process of cefuroxime is not altered by malnutrition. Although differences in $\mathrm{Vz} / \mathrm{F}$ and $\mathrm{Cl} / \mathrm{F}$ between control and malnourished groups were found, these differences might be related to the fraction of dose absorbed by $\mathrm{K}$ and $\mathrm{M}$ groups since cefuroxime is not metabolized, no change in the metabolizing enzymes could alter the clearance of the drug.

The results of the pharmacokinetic study II showed that after the three week period of recovery, group $M$ had a similar pharmacokinetic profile when compared with that of the control group. The body weight of these groups showed no significant differences, suggesting that group $M$ recovered from malnutrition, and consequently the capacity of absorption of cefuroxime was restored. For group K the pharmacokinetic results were similar to those observed in study I. This means that in spite of the three week period in which the animals were fed with a good diet, the capacity of absorption of malnourished animals of this group was not restored. As can be observed, the animals of group $\mathrm{K}$ had $65 \%$ of the mean body weight of the control group and might need a longer period of time to recover their capacity of absorption. This behavior is similar to the observations made in children with kwashiorkor, who in spite of clinical recovery, did not show similar patterns of amino acid transport when compared with normal children because of a slow response of the small intestine morphology to nutritional rehabilitation $(14,15)$. As in study I, no differences were found in group $\mathrm{K}$ for $\mathrm{t}_{1 / 2}$ and MRT.

The changes in pharmacokinetics produced by malnutrition are different depending on the drug and on the route of administration. For example, Lares-Asseff et. al $(43,44)$ found that metronidazole in children showed a different pharmacokinetic pattern in malnourished patients. No significant differences were found in absorption, AUC, and $\mathrm{C}_{\max }$. However, they demonstrated that the elimination half life was significantly longer in severely malnourished children when compared with the values obtained in nutritionally rehabilitated subjects, this change being accompanied by the corresponding decrease in clearance which could be due to modifications in the biotransformation of the drug. These changes indicate that there is a risk of accumulation of the drug after repeated doses and the authors propose that the dose of this drug should be reduced in malnourished children. 
Conclusions. The results of this study show that the absorption of cefuroxime axetil was altered in malnutrition caused by a diet with a low quality protein. After a 3 week recovery period these animals still had alterations in the absorption of cefuroxime axetil while animals fed with a restriction in energy and nutrients but with a good quality protein presented a similar pharmacokinetic pattern to that of the control group of well nourished animals.

The authors thank Leticia Gil and Sarah Carolina González for technical assistance. The authors also would like to thank Dr. Héctor Bourges Rodríguez for his helpful advice.

\section{REFERENCES}

[1]. Farook Jahoor, Asha Badaloo, Marvin Reid and Terrence Forrester. Protein kinetic differences between children with edematous and nonedematous severe childhood undernutrition in the fed and postabsorptive states. J Nutr, 82:792800, 2005.

[2]. Mark J. Manary, Robin L. Broadhead and Kevin E. Yarasheski. Whole-body protein kinetics in marasmus and kwashiorkor during acute infection. Am J Clin Nutr, 67:1205-1209, 1998.

[3]. K. S. Rao. Evolution of kwashiorkor and marasmus. Lancet, 1:709-11, 1974.

[4]. C. R. C. Heard, Sylvia M. Frangi and Pauline M. Wright. Biochemical characteristics of different forms of protein-energy malnutrition: an experimental model using young rats. Br J Nutr, 37:1-21, 1977.

[5]. L. John Hoffer. Clinical nutrition: 1. Proteinenergy malnutrition in the inpatient. CMAJ, 165(10):1345-1349, 2001.

[6]. Asha Badaloo, Marvin Reid, Deanne Soares, Terrence Forrester and Farook Jahoor. Relation between liver fat content and the rate of VLDL apolipoprotein B-100 synthesis in children with protein-energy malnutrition. Am J Clin Nutr, 81:1126-1132, 2005.

[7]. Barry W. Ritz and Elizabeth M. Gardner. Malnutrition and energy restriction differentially affect viral immunity. J Nutr, 136:1141-1144, 2006.

[8]. Marvin Reid, Asha Badaloo, Terrence Forrester, William C. Heird and Farook Jahoor. Response of splanchnic and whole-body leucine kinetics to treatment of children with edematous proteinenergy malnutrition accompanied by infection. Am J Clin Nutr. 76:633-640, 2002.
[9]. Management of the child with a serious infection or severe malnutrition. Geneva: World Health Organization, 2000.

[10]. J. A. Scott, S. Mwarumba, C. Ngetsa, S. Njenga, B. S. Lowe, M. P. Slack, J. A. Berkley, I. Mwangi, K. Maitland, M. English, K. Marsh. Progressive increase in antimicrobial resistance among invasive isolates of Haemophilus influenzae obtained from children admitted to a hospital in Kilifi, Kenya, from 1994 to 2002. Antimicrob Agents Chemother, 49(7):3021-3024, 2005.

[11]. Z. L. Mao, Y. K. Tam and R. T. Coutts. Effect of protein and calorie malnutrition on drug metabolism in rat-in vitro. J Pharm Pharm Sci, 9(1):60-70, 2006.

[12]. Netter KJ. The role of nutrients in detoxification mechanisms. In: Kotsonis FN, Mackey M, Hjelle J, editors. Nutritional toxicology. Raven Press, Ltd., New York, USA 1994. p. 1-17.

[13]. C. S. Catz. Malnutrition and drug metabolism in fetal and neonatal animals. Dev Pharm Therap 15(3-4):211-14, 1990.

[14]. D. R. Brewster, M. J. Manary, I. S. Menzies, E. V. O'Loughlin and R. L. Henry. Intestinal permeability in kwashiorkor. Arch Dis Child, 76:236-241, 1997.

[15]. F. E. Viteri, J. M. Flores, J. Alvarado, M. Behar. Intestinal malabsorption in malnourished children before and during recovery. Relation between severity of protein deficiency and the malabsorption process. Am J Dig Dis, 18:201211, 1973.

[16]. A. Finn, A. Straugun, M. Meyer, J. Chubb. Effect of dose and food on the bioavailability of cefuroxime axetil. Biopharm Drug Dispos, 8:519526, 1987.

[17]. Peter E. O. Williams, Stuart M. Harding. The absolute bioavailability of oral cefuroxime axetil in male and female volunteers after fasting and after food. J Antimicrob Chemother, 13:191-196, 1984.

[18]. Dwight A. Powell, Nancy C. James, Michael J. Ossi, Milap C. Nahata and Karl H. Donn. Pharmacokinetics of cefuroxime axetil suspension in infants and children. Antimicrob Agents Chemother, 35(10):2042-2045, 1991.

[19]. Callum J. Campbell, Laura J. Chantrell, Richard Eastmond. Purification and partial characterization of rat intestinal cefuroxime axetil esterase. Biochem Pharmacol, 36:2317-2324, 1986.

[20]. Gerold L. Mosher, Julianne McBee and David B. Shaw. Esterase activity toward the diastereomers of cefuroxime axetil in the rat and the dog. Pharm Res, 9:687-689, 1992. 
[21]. Nieves Ruiz-Balaguer, Amparo Nacher, Vicente G. Casabo and Matilde Merino. Nonlinear intestinal absorption kinetics of cefuroxime axetil in rats. Antimicrob Agents Chemother, 41(2):445448, 1997.

[22]. N. Ruiz-Balaguer, A. Nacher, V. G. Casabo and M. Merino Sanjuan. Intestinal transport of cefuroxime axetil in rats: absorption and hydrolysis processes. Int J Pharm, 234:101-111, 2002.

[23]. AOAC. Official Methods of Analysis, 15 ${ }^{\text {th }}$ ed.; Association of Analytical Chemists: Arlington, VA, 1990.

[24]. E. F. Hartree. Determination of protein: a modification of the Lowry method that gives a linear photometric response. Anal Biochem, 48:422-427, 1972.

[25]. Jordi Folch, M. Lees, G. H. Sloane Stanley. A simple method for the isolation and purification of total lipids from animal tissues. J Biol Chem, 226:497-509, 1957.

[26]. J. C. Edozien. Experimental kwashiorkor and marasmus. Nature, 220:917-919, 1968.

[27]. Udaya M. Kabadi, Albert B. Eisenstein, Inge Strack. Decrease plasma insulin but normal glucagon in rats fed low protein diets. J Nutr, 106:1247-1253, 1976.

[28]. O. Tulp, S. Gambert, E. S. Horton. Adipose tissue development, growth, and food consumption in protein-malnourished rats. J Lipid Res, 20:47-54, 1979.

[29]. Orien L. Tulp, Edward S. Horton. Effect of prolonged experimental protein malnutrition and of refeeding on growth, adipose tissue development and body composition in rats. $\mathrm{J}$ Nutr, 111:1145-1156, 1981.

[30]. Juan C. Sanahuja and Alfred E. Harper. Amino acid balance and imbalance. XII Effect of amino acid imbalance on self-selection of diet by the rat. J Nutr, 81:363-71, 1963.

[31]. Beverly Musten, Doryne Peace and G. Harvey Anderson. Food intake regulation in the weanling rat: self-selection of protein and energy. J Nutr, 104:563-572, 1974.

[32]. Y. Peng, L. L. Meliza, M. G. Vavich and A. R. Kemmerer. Effects of amino acid imbalance and protein content of diets of food intake and preference of young, adult, and diabetic rats. J Nutr, 105:1395-1404, 1975.
[33]. C. D. Williams. Kwashiorkor. Lancet, 2:1151$1152,1935$.

[34]. K. Fletcher. Observations on the origin of liver fat in infantile malnutrition. Am J Clin Nutr., 19:170174, 1966.

[35]. B. Lewis, J. D. L. Hansen, W. Wittmann, L. H. Krut, F. Stewart. Plasma free fatty acids in kwashiorkor and pathogenesis of the fatty liver. Am J Clin Nutr, 15:161-168, 1964.

[36]. J. E. Iputo, W. W. Wong,P. D. Klein. Impaired dietary lipid oxidation in kwashiorkor. Nutr Res, 18:1187-201, 1998.

[37]. D. Burman. The jejunal mucosa in kwashiorkor. Arch Dis Child, 40(213):526-531, 1965.

[38]. J. P. Stanfield, M. S. R. Hutt, R. Tunnicliffe. Intestinal biopsy in kwashiorkor. Lancet, 11,2(7411):519-523, 1965.

[39]. J. L. Zambonino Infante, J. M. Rouanet, P. Besancon. Mathematical correlation between villus hight and the nutritional state in SpragueDawley rats. Gut, 34:1066-1068, 1993.

[40]. S. K. Bae, S. J. Lee, J. W. Kwon, W. B. Kim, M. G. Lee. Effects of protein-calorie malnutrition on the pharmacokinetics of DA-7867, a new oxazolidinone in rats. J Pharm Pharmacol, 56(5):635-642, 2004.

[41]. Thomas M. Rossi, P. C. Lee, Carolyn M. Young, Aaron Lerner, Emanuel Lebenthal. Effect of nutritional rehabilitation on the development of intestinal brush border disaccharidases of postnatally malnourished weanling rats. Pediatr. Res., 20(8):793-797, 1986.

[42]. Agus Firmansyah, Laurentius Suwandito, Duna Penn, Emanuel Lebenthal. Biochemical and morphological changes in the digestive tract of rats after prenatal and postnatal malnutrition. Am. J. Clin. Nutr., 50:261-268, 1989.

[43]. Ismael Lares-Asseff, Joaquín Cravioto, Pilar Santiago and Bartolomé Pérez-Ortíz. Pharmacokinetics of metronidazole in severely malnourished and nutritionally rehabilitated children. Clin Pharmacol Ther, 51(1):42-50, 1992.

[44]. Ismael Lares-Asseff, Joaquín Cravioto, Pilar Santiago and Bartolomé Pérez-Ortíz. A new dosing regimen for metronidazole in malnourished children. Scan J Infect Dis, 25:115$1121,1993$. 